Article

\title{
Family Firms, Chaebol Affiliations, and Corporate Social Responsibility
}

\author{
Haeyoung Ryu ${ }^{1}$ and Soo-Joon Chae ${ }^{2, *}$ \\ 1 Department of Business Administration, Hansei University, Gunpo-si 15852, Korea; hyryu@hansei.ac.kr \\ 2 Department of Business Administration \& Accounting, Kangwon National University, \\ Chuncheon-si 24341, Korea \\ * Correspondence: sjchae@kangwon.ac.kr; Tel.: +82-33-250-6172
}

Citation: Ryu, H.; Chae, S.-J. Family Firms, Chaebol Affiliations, and Corporate Social Responsibility. Sustainability 2021, 13, 3016. https:// doi.org/10.3390/su13063016

Academic Editor: Jennifer Martínez-Ferrero

Received: 10 February 2021

Accepted: 8 March 2021

Published: 10 March 2021

Publisher's Note: MDPI stays neutral with regard to jurisdictional claims in published maps and institutional affiliations.

Copyright: (c) 2021 by the authors. Licensee MDPI, Basel, Switzerland. This article is an open access article distributed under the terms and conditions of the Creative Commons Attribution (CC BY) license (https:// creativecommons.org/licenses/by/ $4.0 /)$.
Abstract: This study analyzes the corporate social responsibility (CSR) activities of family-owned firms by investigating public companies in Korea. By nature of their governance structures, which are aligned with the interests of their shareholders and management, family firms are managed from a long-term perspective based on a sense of ownership. While CSR implementation entails investment costs, it ultimately increases firm value by enhancing the firm's reputation and brand image. As such, family firms are expected to be more active than non-family firms regarding CSR investments. We conducted an empirical analysis based on the Korean Economic Justice Institute Index (KEJI Index) from the Citizens' Coalition for Economic Justice and found that family firms' CSR scores were higher than those of non-family firms. This indicates that family firms are relatively more active in their CSR activities, as they are managed from a long-term viewpoint. However, family firms classified as large-scale corporate groups (chaebols) had lower CSR activity levels. This is because when family firms are classified as corporate groups, they can enjoy monopolistic market positioning through their subsidiaries, and are thus more likely to utilize the resources originally required for CSR in other projects that conform to the pursuit of firm interests.

Keywords: family firms; CSR activities; large-scale corporate groups (chaebol); KEJI index scores

\section{Introduction}

While many scholars and institutions have defined corporate social responsibility (CSR), there is a lack of clear theoretical foundations regarding the role and definition of CSR. Frooman [1] defines CSR as corporate activities that can influence the wealth of a firm's stakeholders, whereas McWilliams and Siegel [2] explain CSR as a firm's attempt to create social wealth beyond what is required of the firm legally and in terms of its interests. Hopkins [3] explains CSR as a concept related to treating a firm's stakeholders in an ethical or responsible manner. Many scholars explain CSR activities as a concept that relates to the responsibility of the firm to society and its stakeholders [4-6] and view it as a series of voluntary activities by the firm to better society and the environment [7]. In other words, while there is no single definition of CSR, it is typically accepted as a firm's voluntary activity, which goes beyond its legal requirements, in the interests of its employees, consumers, society, and the environment.

However, when a firm engages in CSR activities, it experiences direct costs and faces a disadvantage, as profits decline due to these expenses. Therefore, Freedman [8] argued that CSR activities should only be performed with the premise of increasing profits for a firm and that, if a firm focuses excessively on CSR, it damages firm value.

However, firms engage in CSR activities because there is a positive relationship between CSR and firm value. Existing studies argue that since CSR activities advance the reputation and brand image of a firm, CSR investments lead to long-term increases in firm value. Heal [9] argued that CSR activities can increase a firm's reputation by reducing 
conflicts with stakeholders and maximizing stakeholder trust. At the same time, CSR can be an optimal method for minimizing potential conflicts of interest among stakeholders [10].

\section{Literature Review and Hypotheses}

This study aims to analyze the levels of CSR activities in family and non-family firms in Korea by focusing on the former. To verify the hypotheses of this study, it is necessary to understand how to define family firms. Thus far, there has been no unified definition of a family firm, and existing studies have defined family firms using diverse and different methods. In summary, the defining criteria of family firms according to existing research can be divided into the following three factors: first, whether the beneficial owner of the firm, that is, the controlling family, participates in the management of the firm; second, whether the controlling family has a certain level (or more) of firm ownership (shareholding); and third, a mix of the previous two criteria. While the definitions of family firms in existing studies lack consistency, family firms are generally defined as firms that are controlled by their founders and their families, or firms whose ownership and management are both controlled by controlling shareholders and their families [11-15]. Family firms have special governance structures where the shareholders and management of the firm are the same, and thus, there are aligned interests between shareholders and management. Furthermore, there are other benefits, such as longer-term management perspectives as compared to firms run by professional CEOs [16]. However, by classifying shareholders into controlling shareholders and external minority shareholders, the clash between their interests may be exacerbated. Given these characteristics of the governance structure, family and non-family firms have several differences. Jensen and Meckling [17] studied agent costs and ownership structures and reported that family firms' ownership structures with voting right concentrations have a positive influence on firm performance. On the one hand, Demsetz and Lehn [16] asserted that family firms have less severe issues with agent problems between the largest shareholders and management and are incentivized to maximize firm value. Furthermore, Anderson and Reeb [12] asserted that in family firms, shareholders have the incentive and ability to provide oversight of management, allowing for effective management. On the other hand, Gilson and Gordon [18] argued that the agent problem that occurs from the separation of ownership and management in family firms is less significant and that the agent problem between controlling and minority shareholders is pronounced.

The importance of CSR activities as a critical condition for a firm to become sustainable is coming into the spotlight worldwide. CSR activities are based on stakeholder theory, which argues that it is necessary for management during decision-making to consider not only shareholders, but also various stakeholders connected directly and indirectly with the firm to ensure long-term firm growth [10]. Accordingly, existing studies on CSR activities have examined the influence of CSR activities on firm value and financial performance.

CSR activities have been reported to increase a firm's reputation, lead to increased revenues, and lower sales management costs in the long term; firms engaging in CSR activities have been found to have a higher value than those who do not engage in such activities [15]. Additionally, more socially conscious investors desire to pay higher premiums for firms that engage in more CSR activities, which leads to higher market values and lower costs of equity capital for such firms $[19,20]$.

However, CSR activities require significant initial spending, and it is unclear whether a firm's efforts to deliver corporate social activity are adequately reflected in firm value [21]. The occurrence of excessive CSR expenses naturally leads to declining profitability, and some argue that the inability to choose projects with higher profitability may lead to decreased effectiveness in increasing shareholder value [22].

Early research on the relationship between CSR activities and financial performance has argued that costs associated with CSR may not exist for a firm's competitors, which leads to a negative influence on financial performance [23]; however, recent studies indicate that firms that actively engage in CSR activities can avoid government regulations, leading 
to lower regulatory costs [20], and are attractive to consumers who take interest in social issues, thereby achieving superior revenues and financial performance [24]. Even in Korea, firms engaging in CSR activities have been reported to have higher revenues and superior financial performance as compared to firms that do not engage in such activities [25].

Recently, with CSR activities being regarded as an inevitable social trend, it has been argued that expenditures on CSR activities should be viewed as strategic investment activities that bring benefits to society and profits to the firm instead of costs. Extant studies have defined CSR activities that satisfy both the firm and society as strategic CSR activities and have suggested that firms can enjoy competitive advantages by strategically utilizing the value of their CSR activities [26-29]. Furthermore, according to Cho et al. [25], who examined the influence of continued CSR activities on a firm's financial performance, continued CSR activities can lead to a positive influence on management performance. These results indicate that CSR activities should be utilized as a part of sustainable management strategies.

However, CSR activities typically occur over the long term and are accompanied by costs that are not directly related to the profitability of a firm. Some studies indicate that investing in CSR activities leads to significant increases in short-term costs as compared to long-term benefits, which can cause reductions in firm value or management performance [22]. In other words, as CSR activity is a type of investment [2], the decision to engage in CSR activities would likely be determined by the incentives in the corporate governance structure [30].

Noting that family firms are managed with a longer-term outlook as compared to non-family firms, we expect that family firms would be incentivized to actively pursue CSR activities that positively impact firm value in the long term and thus put forth the following hypothesis.

Hypothesis 1. Family firms are more engaged in CSR activities as compared to non-family firms.

The word "chaebol" refers to a large-scale, family-run conglomerate, such as Samsung Electronics, and carries wider symbolic meaning in the context of Korean business. As chaebols are such a significant feature of the Korean economy, the word signifies Korean growth in a global context, but also alludes to the nepotism, factionalism, and other cultural issues supposedly fostered by the prevalence of such firms. According to the Korea Fair Trade Commission, Korean chaebols are a single group of companies that involve the management of various subsidiaries whose ownership is focused on a single individual or the individual's relatives. A key characteristic of Korean chaebols is that they are formed around many firms that conduct business in different markets, in which they often control monopolistic positions. Furthermore, such corporate groups are de-facto controlled by a single beneficial owner, or the owner's family and relatives, and their early growth has typically been propelled by governmental support and protection.

Although monopolistic markets experience a lack of competing firms and bring easy profits [31], in a competitive market, intensifying competition can allow firms to engage in CSR to obtain competitive advantages, which leads to positive influences on their financial performance. However, in a low-competition market, it becomes easier to obtain profits without significant investment or efforts as the industry becomes more monopolized, indicating that CSR activities may become additional expenses.

Controlling shareholders who are interested in short-term performance in a monopoly tend to reduce expenditures on CSR activities that have uncertain returns and give rise to long-term increases in firm value [32]. In other words, controlling shareholders are incentivized to direct resources to projects that pursue firm profits rather than investing in CSR activities, which are not directly linked to the firm's profitability.

Furthermore, family firms whose management is concentrated in a small number of family members may experience comparatively weaker monitoring mechanisms, leading to ineffective management formats $[33,34]$. Such incentives are expected to be stronger when family firms are classified as large-scale conglomerates. 
Therefore, we expect that family firms' CSR activities differ based on whether they are chaebols, and we put forth the second hypothesis as follows.

Hypothesis 2. If the family firm is a chaebol, it will be passive toward CSR activities.

We found that when family members of the controlling shareholder comprise members of the board, it is likely that they will have a significant influence on the board of directors. In addition, for the purposes of this study, we established the condition that controlling shareholders owning more than $5 \%$ of outstanding shares signify a family firm. Family firms that are thus identified comprise a majority of the public companies making up the Korea Composite Stock Price Index (KOSPI), and some of these are chaebols with significant influence over the Korean economy. This study first organizes the characteristics of family firms in which the controlling shareholder participates in management and explores how such characteristics influence CSR activities. Furthermore, this study analyzes whether investments in CSR activities differ when family firms are considered chaebols.

The remainder of this paper is structured as follows. Section 3 presents the study model and the samples used. Section 4 reports the results of the empirical analysis of the hypotheses and research results, including an additional analysis. Finally, Section 5 presents the discussion and conclusions of the study.

\section{Materials and Methods}

This study examines nonfinancial public companies listed between 2012 and 2016 in the Korean securities markets with December as their fiscal year-end. Financial information and shareholding data were extracted from KIS-VALUE, and the scores related to CSR activities were collected using the Korean Economic Justice Institute Index (KEJI Index) as reported by the Institute of Economic Justice, which is affiliated with the Citizens' Coalition for Economic Justice. To minimize the influence of the extreme values of each variable on the analysis results, this study winsorized major independent variables with values belonging to the top and bottom $1 \%$. This resulted in 2335 firm-year datasets as the final sample, which was composed of 1121 firm-year sets with CSR scores and 1214 firm-year sets without CSR scores.

Family members of controlling shareholders can exert a significant influence if they have positions such as the CEO or chairman of the board [35]. For cases in which family members own companies and participate in management directly, this study considered that it would be possible for the family members to directly influence information disclosure policies. This study therefore defined family firms as cases where the controlling shareholder or a family member was a CEO. Additionally, this study referenced existing studies that argued that definitions of family firms should consider both management participation and shareholding $[36,37]$, and thus set $5 \%$ as the reference point when considering shareholding by the controlling shareholder. Faccio et al. [35], La Porta et al. [38], and Classens et al. [39], who studied the abuse of control over minority shareholders, assumed that controlling shareholders were shareholders with more than $5 \%$ shareholding. Andres [40] analyzed the management performance of family firms in German disclosure environments, where $5 \%$ or more in shareholding is subject to disclosure, and defined family firms as firms whose shareholding is held at $5 \%$ or more by the controlling family or by an affiliate for sample consistency. For these reasons, this study also classified cases in which the controlling shareholder has more than $5 \%$ shareholding and is the $\mathrm{CEO}$ as the measure of family firms (FAM2).

This study utilized the KEJI Index to measure CSR activity levels in firms. Table 1 shows the KEJI Index of Korea as published by the Institute of Economic Justice under the Citizens' Coalition for Economic Justice. It is an indicator of corporate social performance measured for public companies listed on the Korea Stock Exchange since 1991, with the top 200 companies reported annually. The KEJI Index is composed of six categories, including soundness ( 25 points), fairness ( 20 points), social service activities (15 points), customer protection (15 points), environmental protection (10 points), and employee satisfaction 
(15 points), and the CSR activity levels of individual firms are assessed based on the total CSR scores.

Table 1. Korean Economic Justice Institute Index (KEJI Index).

\begin{tabular}{lll}
\hline Item (Score) & Subsection & Score \\
\hline \multirow{3}{*}{ Soundness (25) } & Soundness of corporate governance & 11 \\
& Soundness of investment expenditure & 6 \\
& Soundness of capital financing & 8 \\
\hline \multirow{2}{*}{ Fairness of firm activities (20) } & Fair trade & 14 \\
& Transparency & 6 \\
\hline \multirow{3}{*}{ Social service activities (15) } & Employment equality and expansion & 7 \\
& Contribution to public welfare & 6 \\
& National financial contribution & 2 \\
\hline \multirow{3}{*}{ Customer protection (15) } & Protection of consumer rights & 7 \\
& Compliance with consumer law & 5 \\
& Consumer safety & 3 \\
\hline \multirow{2}{*}{ Environmental protection (10) } & Environmental reform & 5 \\
& Environmental assessment & 2 \\
& Violation and pollution & 3 \\
\hline \multirow{2}{*}{ Employee satisfaction (15) } & Health and safety in the workplace & 3.5 \\
& Investment in human resources & 2 \\
& Wages and welfare services & 2.5
\end{tabular}

KEJI scores (scores on the KEJI Index) are based on quantitative evaluations. In this study, aggregate scores from the quantitative evaluation were used, and the scores of the subcategories are listed in the third column.

This study focuses on the top 200 companies with CSR scores included in the list from the KEJI Index and measures CSR activity levels based on total CSR scores. In the additional analysis, this study assesses CSR activity levels in public companies in securities markets by deriving a dummy variable, CSRD, which is assigned a value of 1 when a company is on the top 200 list in the KEJI Index and 0 when a company is not on the list. In other words, companies that are included in the top 200 list in the KEJI Index are classified as active in CSR activities, and all other companies are considered to be inactive in CSR activities.

This study set the following research model to analyze CSR activity levels in family firms. Models (1) and (2) are linear regression analyses with dependent variables of CSR activity scores designed to test Hypotheses 1 and 2.

$$
\begin{aligned}
\text { CSR Score }_{i, \mathrm{t}}=\beta_{0} & +\beta_{1} \mathrm{FAM}_{\mathrm{i}, \mathrm{t}}+\beta_{2} \mathrm{CHA}_{\mathrm{i}, \mathrm{t}}+\beta_{3} \mathrm{SIZE}_{\mathrm{i}, \mathrm{t}}+\beta_{4} \mathrm{LEV}_{\mathrm{i}, \mathrm{t}}+\beta_{5} \mathrm{MB}_{\mathrm{i}, \mathrm{t}} \\
& +\beta_{6} \mathrm{ROE}_{\mathrm{i}, \mathrm{t}}+\beta_{7} \mathrm{LAR}_{\mathrm{i}, \mathrm{t}}+\beta_{8} \mathrm{FOR}_{\mathrm{i}, \mathrm{t}}+\sum \mathrm{IND}+\sum \mathrm{YR}+\varepsilon_{\mathrm{i}, \mathrm{t}}
\end{aligned}
$$

$$
\begin{aligned}
\text { CSR Score }_{i, t}=\beta_{0} & +\beta_{1} \mathrm{FAM}_{\mathrm{i}, \mathrm{t}}+\beta_{2} \mathrm{FAM} \times \mathrm{CHA}_{\mathrm{i}, \mathrm{t}}+\beta_{3} \mathrm{CHA}_{\mathrm{i}, \mathrm{t}}+\beta_{4} \mathrm{SIZE}_{\mathrm{i}, \mathrm{t}} \\
& +\beta_{5} \mathrm{LEV}_{\mathrm{i}, \mathrm{t}}+\beta_{6} \mathrm{MB}_{\mathrm{i}, \mathrm{t}}+\beta_{7} \mathrm{ROE}_{\mathrm{i}, \mathrm{t}}+\beta_{8} \mathrm{LAR}_{\mathrm{i}, \mathrm{t}}+\beta_{9} \mathrm{FOR}_{\mathrm{i}, \mathrm{t}}+\sum \mathrm{IND} \\
& +\sum \mathrm{YR}+\varepsilon_{\mathrm{i}, \mathrm{t}}
\end{aligned}
$$

where:

CSR Score $=$ CSR scores evaluated with the KEJI Index;

FAM = FAM1, FAM2;

FAM1 $=1$ if the controlling family is a member of the board of directors, and 0 otherwise;

FAM2 $=1$ if the controlling family with an ownership interest ratio of $5 \%$ or more is a member of the board of directors, and 0 otherwise;

$\mathrm{CHA}=1$ if the firm belongs to large business groups (chaebol), and 0 otherwise;

SIZE $=\log$ (total assets);

$\mathrm{LEV}=$ total liabilities/total assets;

$\mathrm{MB}=$ the ratio of the market value to the book value of total assets; 


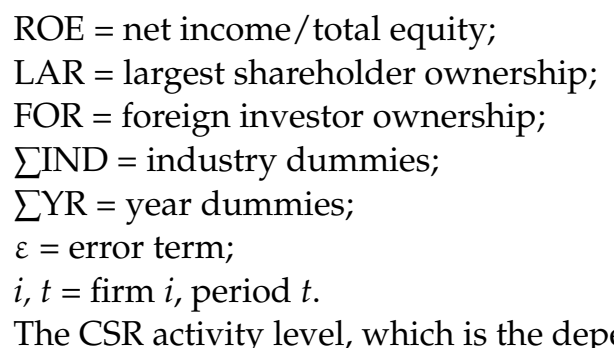
scores on the KEJI Index, as described abov whether the firm is a family firm or not, and the coefficient value of FAM, $\beta 1$, is the coefficient of interest. The control variables include variables that are known to influence CSR activities according to existing studies [41-43]. Due to the significant influence of chaebols on the Korean economy, this study expected CSR activity levels to change based on whether a company was considered a chaebol. The dummy variable CHA was used to indicate whether or not the firm is a chaebol. Specifically, chaebols were classified based on the limitations on mutual investment, as disclosed by the Korea Fair Trade Commission. Conglomerates with mutual investment limitations are Korean conglomerates with assets exceeding 10 trillion KRW between all affiliates. Furthermore, since larger companies draw more attention from the markets and are more incentivized to actively engage in CSR, firm size (SIZE) was considered as a control variable. Companies with high debt-to-equity ratios (LEV) cannot afford to engage in social service activities because of their financing costs. However, firms with high growth and profitability have the wherewithal to invest in social service activities. Therefore, the market-to-book ratio of net assets (MB) and return on equity (ROE) ratios were used as control variables. In addition, this study included shareholding by the largest shareholder (LAR) and foreign investor ownership (FOR) as variables of corporate governance structures. Lastly, we included year and industry dummy variables to control for the effects arising from differences in year and industry.

\section{Results}

\subsection{Descriptive Statistics and Correlation Analysis}

Table 2 shows the descriptive statistics of the variables that were collected and measured in this study. For the top 200 firms included in the KEJI Index list with CSR scores, the mean CSR score and standard deviation were 61.998 and 3.055, respectively. For FAM1 and FAM2, which were family firm variables, the mean (median) values were 0.744 (1) and 0.735 (2), respectively, indicating that family firms in which controlling family shareholders participated in management constituted over $70 \%$ of the sample. In the case of the control variables, there were no significant differences between the mean and median values. The mean values of LAR and FOR were 0.439 and 0.100 , respectively, indicating that in the sample firms, the shareholding by the largest shareholder and foreigners averaged $43 \%$ and $10 \%$, respectively.

Table 3 shows the Pearson correlations between the variables used in this study. The CSR activity scores showed a significant positive relationship with FAM2, a measure of family firms, at the $10 \%$ significance level. Meanwhile, CSR activity scores showed significant positive correlations with the control variables of SIZE (firm size), MB (growth), ROE (profitability), and FOR (foreign ownership), and significant negative correlations with LEV (debt-to-equity ratio) and LAR (shareholding by the largest shareholder). We analyzed the variation inflation factor (VIF) to check for multiple collinearity and found that the VIF values of all variables were less than 10, and thus, we concluded that the problem of multiple collinearity did not significantly impact the regression analysis in this study. 
Table 2. Descriptive statistics $(n=1121)$.

\begin{tabular}{cccccccc}
\hline Variable & Mean & SD & Min & $\mathbf{2 5 \%}$ & Median & $\mathbf{7 5 \%}$ & Max \\
\hline CSR Score & 61.998 & 3.055 & 51.635 & 59.938 & 61.974 & 64.070 & 72.158 \\
FAM1 & 0.744 & 0.437 & 0.000 & 0.000 & 1.000 & 1.000 & 1.000 \\
FAM2 & 0.735 & 0.441 & 0.000 & 0.000 & 1.000 & 1.000 & 1.000 \\
CHA & 0.222 & 0.416 & 0.000 & 0.000 & 0.000 & 0.000 & 1.000 \\
SIZE & 26.655 & 1.370 & 24.130 & 25.737 & 26.412 & 27.280 & 31.548 \\
LEV & 0.846 & 1.102 & 0.001 & 0.300 & 0.579 & 1.105 & 22.829 \\
MB & 1.267 & 1.066 & 0.217 & 0.659 & 0.979 & 1.441 & 7.498 \\
ROE & 0.075 & 0.205 & -1.830 & 0.031 & 0.064 & 0.099 & 5.070 \\
LAR & 0.439 & 0.155 & 0.069 & 0.327 & 0.446 & 0.534 & 0.900 \\
FOR & 0.104 & 0.139 & 0.000 & 0.013 & 0.043 & 0.145 & 0.897
\end{tabular}

This table summarizes the main variables of interest. Variable definitions: CSR score = CSR scores evaluated with the KEJI Index; FAM1 = 1 if the controlling family is a member of the board of directors, and 0 otherwise; FAM2 = 1 if the controlling family with an ownership interest ratio of $5 \%$ or more is a member of the board of directors, and 0 otherwise; $\mathrm{CHA}=1$ if the firm belongs to large business groups (chaebol), and 0 otherwise. SIZE = Ln (total assets); $\mathrm{LEV}=$ total liabilities/total assets; $\mathrm{MB}=$ the ratio of the market value to the book value of total assets; $\mathrm{ROE}=$ net income/total equity; $\mathrm{LAR}=$ largest shareholder ownership; FOR = foreign investor ownership.

Table 3. Pearson correlation $(n=1121)$.

\begin{tabular}{|c|c|c|c|c|c|c|c|c|c|}
\hline & FAM1 & FAM2 & CHA & SIZE & LEV & MB & ROE & LAR & FOR \\
\hline $\begin{array}{l}\text { CSR } \\
\text { Score }\end{array}$ & $\begin{array}{c}0.037 \\
(0.219)\end{array}$ & $\begin{array}{c}0.052 \\
(0.081)\end{array}$ & $\begin{array}{l}-0.015 \\
(0.607)\end{array}$ & $\begin{array}{c}0.136 \\
(<0.001)\end{array}$ & $\begin{array}{l}-0.095 \\
(<0.001)\end{array}$ & $\begin{array}{c}0.157 \\
(<0.001)\end{array}$ & $\begin{array}{c}0.073 \\
(0.015)\end{array}$ & $\begin{array}{l}-0.302 \\
(<0.001)\end{array}$ & $\begin{array}{c}0.268 \\
(<0.001)\end{array}$ \\
\hline FAM1 & & $\begin{array}{c}0.977 \\
(<0.001)\end{array}$ & $\begin{array}{c}-0.35 \\
(<0.001)\end{array}$ & $\begin{array}{l}-0.263 \\
(<0.001)\end{array}$ & $\begin{array}{l}-0.102 \\
(<0.001)\end{array}$ & $\begin{array}{l}-0.183 \\
(<0.001)\end{array}$ & $\begin{array}{l}-0.032 \\
(0.288)\end{array}$ & $\begin{array}{c}0.019 \\
(0.523)\end{array}$ & $\begin{array}{l}-0.248 \\
(<0.001)\end{array}$ \\
\hline FAM2 & & & $\begin{array}{l}-0.341 \\
(<0.001)\end{array}$ & $\begin{array}{l}-0.251 \\
(<0.001)\end{array}$ & $\begin{array}{l}-0.105 \\
(<0.001)\end{array}$ & $\begin{array}{l}-0.173 \\
(<.001)\end{array}$ & $\begin{array}{l}-0.029 \\
-0.337\end{array}$ & $\begin{array}{c}0.007 \\
-0.817\end{array}$ & $\begin{array}{l}-0.236 \\
(<0.001)\end{array}$ \\
\hline CHA & & & & $\begin{array}{c}0.618 \\
(<0.001)\end{array}$ & $\begin{array}{c}0.113 \\
(<0.001)\end{array}$ & $\begin{array}{c}0.092 \\
(<0.001)\end{array}$ & $\begin{array}{c}0.005 \\
-0.868\end{array}$ & $\begin{array}{l}-0.058 \\
-0.053\end{array}$ & $\begin{array}{c}0.25 \\
(<0.001)\end{array}$ \\
\hline SIZE & & & & & $\begin{array}{c}0.089 \\
(<0.001)\end{array}$ & $\begin{array}{c}0.065 \\
-0.029\end{array}$ & $\begin{array}{c}0.025 \\
-0.406\end{array}$ & $\begin{array}{l}-0.109 \\
(<0.001)\end{array}$ & $\begin{array}{c}0.483 \\
(<0.001)\end{array}$ \\
\hline LEV & & & & & & $\begin{array}{c}0.101 \\
(<0.001)\end{array}$ & $\begin{array}{c}0.071 \\
-0.017\end{array}$ & $\begin{array}{l}-0.106 \\
(<0.001)\end{array}$ & $\begin{array}{l}-0.124 \\
(<0.001)\end{array}$ \\
\hline $\mathrm{MB}$ & & & & & & & $\begin{array}{c}0.131 \\
(<0.001)\end{array}$ & $\begin{array}{c}-0.17 \\
(<0.001)\end{array}$ & $\begin{array}{c}0.298 \\
(<0.001)\end{array}$ \\
\hline ROE & & & & & & & & $\begin{array}{l}-0.051 \\
-0.085\end{array}$ & $\begin{array}{c}0.09 \\
(<0.001)\end{array}$ \\
\hline LAR & & & & & & & & & $\begin{array}{l}-0.191 \\
(<0.001)\end{array}$ \\
\hline
\end{tabular}

This table presents Pearson's correlation coefficients among the main variables. Values in parentheses are $p$-values. See Section 2 for variable definitions.

\subsection{Results of the Multivariate Analysis}

\subsubsection{Hypothesis 1: The Impact of Family Firms on CSR}

Table 4 shows the results of the analysis of the CSR activity scores of family firms included in the top 200 list for the KEJI Index. The results indicated that the values of the regression coefficient $\beta 1$, which show the influence of family firms (FAM1 and FAM2) on CSR activity levels, were 0.585 and 0.544 , respectively, and were found to be significantly positive at the $1 \%$ significance level. Specifically, family firms in which controlling family shareholders participated in management (FAM1) had high total CSR scores and family firms where the shareholding by the controlling shareholder from the family was $5 \%$ or above (FAM2) also had higher total CSR scores as compared to firms that did not meet these conditions. These results indicate that family firms, which are not professionally managed companies that are assessed based on performance, are not fixated on short-term 
results. As such, they have the incentive to actively engage in CSR activities, which may take place over the long term but ultimately contribute to increasing firm value [44-48].

Table 4. Hypothesis 1: The effect of the family firms on corporate social responsibility (CSR).

\begin{tabular}{|c|c|c|c|c|}
\hline \multirow{2}{*}{ Variables } & \multicolumn{2}{|c|}{ (1) $Y=$ CSR SCORE } & \multicolumn{2}{|c|}{ (2) $Y=$ CSR SCORE } \\
\hline & Coef. & $t$-Value & Coef. & $t$-Value \\
\hline Intercept & 55.867 & $(25.84)^{* * *}$ & 55.848 & $(25.8) * * *$ \\
\hline FAM1 & 0.585 & $(2.98)^{* * *}$ & & \\
\hline FAM2 & & & 0.544 & $(2.72) * * *$ \\
\hline $\mathrm{CHA}$ & -0.305 & $(-1.16)$ & -0.319 & $(-1.21)$ \\
\hline SIZE & 0.262 & $(3.21)^{* * *}$ & 0.264 & $(3.24)^{* * *}$ \\
\hline LEV & -0.247 & $(-3.15)^{* * *}$ & -0.250 & $(-3.19)^{* * *}$ \\
\hline $\mathrm{MB}$ & 0.292 & $(3.61)^{* * *}$ & 0.292 & $(3.61)^{* * *}$ \\
\hline ROE & 0.409 & (1.06) & 0.410 & $(1.07)$ \\
\hline LAR & -4.710 & $(-8.77)^{* * *}$ & -4.726 & $(-8.8)^{* * *}$ \\
\hline FOR & 2.918 & $(4.01)^{* * *}$ & 2.888 & $(3.97)^{* * *}$ \\
\hline$\Sigma \mathrm{IND}, \Sigma \mathrm{YR}$ & \multicolumn{2}{|c|}{ Included } & \multicolumn{2}{|c|}{ Included } \\
\hline Adjusted R2 & \multicolumn{2}{|c|}{0.2772} & \multicolumn{2}{|c|}{0.2781} \\
\hline F Statistics & \multicolumn{2}{|c|}{$18.89^{* * *}$} & \multicolumn{2}{|c|}{$18.98^{* * *}$} \\
\hline Sample Size & \multicolumn{2}{|c|}{1121} & \multicolumn{2}{|c|}{1121} \\
\hline
\end{tabular}

In the case of control variables, larger firms (SIZE) with higher growth (MB) were more likely to invest in CSR activities. Firms with higher debt-to-equity ratios (LEV) and higher shareholding by the largest shareholder (LAR) were more passive in terms of CSR activities.

4.2.2. Hypothesis 2: The Impact of Chaebols on the Relationship between Family Firms and CSR

Table 5 shows the results of the analysis of the differences in investment levels for CSR activities when a family firm is classified as a chaebol. The results indicated that the values of the regression coefficient $\beta 2$, which measured the influence of a family firm as a chaebol through FAM1 $\times$ CHA and FAM2 $\times$ CHA on CSR scores, were -2.162 and -2.191 , respectively, showing significant negative values at the $1 \%$ level. The results indicate that given a monopolistic status, even family firms that manage with longer-term perspectives reduce expenditure on CSR activities that require long-term expenditure, as the return on such investments is uncertain.

Hypothesis 1 was established to analyze the level of CSR activities for Korean family companies, regardless of whether a company is considered a chaebol as well as a family company. 
Table 5. Hypothesis 2: The effect of the relationship between family firms and chaebols on CSR.

\begin{tabular}{|c|c|c|c|c|}
\hline \multirow{2}{*}{ Variables } & \multicolumn{2}{|c|}{ (1) $Y=$ CSR SCORE } & \multicolumn{2}{|c|}{ (2) $\mathrm{Y}=\mathrm{CSR}$ SCORE } \\
\hline & Coef. & $t$-Value & Coef. & $t$-Value \\
\hline Intercept & 54.649 & $(25.41)^{* * *}$ & 54.522 & $(25.37)^{* * *}$ \\
\hline FAM1 & 1.245 & $(5.24)^{* * *}$ & & \\
\hline FAM2 & & & 1.274 & $(5.49) * * *$ \\
\hline $\mathrm{FAM} 1 \times \mathrm{CHA}$ & -2.162 & $(-5.32)^{* * *}$ & & \\
\hline $\mathrm{FAM} 2 \times \mathrm{CHA}$ & & & -2.191 & $(-5.43)^{* * *}$ \\
\hline CHA & 0.927 & $(2.65) * * *$ & 0.932 & $(2.7)^{* * *}$ \\
\hline SIZE & 0.284 & $(3.52)^{* * *}$ & 0.287 & $(3.56)^{* * *}$ \\
\hline LEV & -0.287 & $(-3.7)^{* * *}$ & -0.284 & $(-3.66)^{* * *}$ \\
\hline MB & 0.280 & $(3.5)^{* * *}$ & 0.277 & $(3.48)^{* * *}$ \\
\hline ROE & 0.419 & (1.1) & 0.421 & (1.11) \\
\hline LAR & -4.475 & $(-8.4)^{* * *}$ & -4.433 & $(-8.32)^{* * *}$ \\
\hline FOR & 2.906 & $(4.04)^{* * *}$ & 2.886 & $(4.02)^{* * *}$ \\
\hline$\Sigma$ IND, $\Sigma$ YR & \multicolumn{2}{|c|}{ Included } & \multicolumn{2}{|c|}{ Included } \\
\hline Adjusted R2 & \multicolumn{2}{|c|}{0.2948} & \multicolumn{2}{|c|}{0.2964} \\
\hline F Statistics & \multicolumn{2}{|c|}{$19.72 * * *$} & \multicolumn{2}{|c|}{$19.87^{* * *}$} \\
\hline Sample Size & \multicolumn{2}{|c|}{1121} & \multicolumn{2}{|c|}{1121} \\
\hline
\end{tabular}

This table presents the results of testing the effects of family firms and chaebols on CSR activities. We performed a robust standard-error clustered regression analysis at the firm level using KEJI Index scores as the dependent variable. See Section 2 for variable definitions. ${ }^{* * *}$ represents significance at the $1 \%, 5 \%$, and $10 \%$ levels, respectively.

In Hypothesis 2, we tried to find out what the incremental characteristics of family companies and chaebol companies represent compared to general family companies. Therefore, the interaction terms, such as FAM1 $\times$ CHA and FAM2 $\times$ CHA, were included in the analysis model and verified. In the case of FAM1, an incremental effect of -2.162 was shown in addition to the existing 1.245. Even when family businesses were defined with the FAM2 variable, the result of the study showed that, in addition to the existing 1.274 , an incremental effect of -2.191 was observed, indicating that the family businesses that are conglomerates do not actively invest in CSR.

\subsection{Additional Analysis}

\subsubsection{Additional Analysis 1: CSR as a Dummy Variable}

In the additional analysis, we verified the hypotheses for all public companies in the sample period. In other words, the additional analysis expands on the sample by classifying the firms included in the KEJI Index list as engaging actively in CSR and those not included as not.

Table 6 shows the analysis results of the CSR activity levels of family firms based on their inclusion in the KEJI Index. The CSR dummy, which is the dependent variable of the additional analysis, is a dummy variable that is coded as 1 when a firm is included in the KEJI Index, and 0 otherwise. As a result of a logit analysis, the values of regression coefficient $\beta 1$, which show the influence of family firm status (FAM1, FAM2) on the CSR activity level, were 0.285 and 0.268 , respectively, showing significantly positive values at the $1 \%$ level. These results are consistent with the main hypothesis verification results. 
Table 6. Additional analysis 1: CSR as a dummy variable.

\begin{tabular}{|c|c|c|c|c|c|c|c|c|}
\hline \multirow{2}{*}{ Variables } & \multicolumn{2}{|c|}{ (1) $Y=$ CSR Dummy } & \multicolumn{2}{|c|}{ (2) $Y=$ CSR Dummy } & \multicolumn{2}{|c|}{ (3) $Y=$ CSR Dummy } & \multicolumn{2}{|c|}{ (4) $Y=$ CSR Dummy } \\
\hline & Coef. & $z$-Value & Coef. & $z$-Value & Coef. & $z$-Value & Coef. & $z$-Value \\
\hline Intercept & 6.257 & $(28.36)^{* * *}$ & 6.301 & $(28.84) * * *$ & 5.963 & $(25.59) * * *$ & 6.001 & $(25.91) * * *$ \\
\hline FAM1 & 0.285 & $(7.40)^{* * *}$ & & & 0.475 & $(12.97)^{* * *}$ & & \\
\hline FAM2 & & & 0.268 & $(6.73)^{* * *}$ & & & 0.441 & $(11.57)^{* * *}$ \\
\hline $\mathrm{FAM} 1 \times \mathrm{CHA}$ & & & & & -0.515 & $(5.74)^{* *}$ & & \\
\hline FAM2 $\times$ CHA & & & & & & & -0.477 & $(4.96)^{* *}$ \\
\hline CHA & 0.092 & $(0.41)$ & 0.088 & $(0.38)$ & 0.386 & $(4.20)^{* *}$ & 0.356 & $(3.64)^{*}$ \\
\hline SIZE & -0.273 & $(37.53)^{* * *}$ & -0.274 & $(37.87)^{* * *}$ & -0.269 & $(36.38) * * *$ & -0.269 & $(36.44) * * *$ \\
\hline LEV & -0.004 & $(0.02)$ & -0.004 & $(0.02)$ & -0.006 & $(0.05)$ & -0.006 & $(0.05)$ \\
\hline $\mathrm{MB}$ & -0.046 & (1.33) & -0.048 & (1.43) & -0.047 & (1.35) & -0.049 & (1.48) \\
\hline ROE & 0.204 & $(3.25) *$ & 0.205 & $(3.26) *$ & 0.196 & $(3.11) *$ & 0.198 & $(3.14) *$ \\
\hline LAR & 1.240 & $(20.44)^{* * *}$ & 1.245 & $(20.62)^{* * *}$ & 1.301 & $(22.28)^{* * *}$ & 1.305 & $(22.41)^{* * *}$ \\
\hline FOR & 1.970 & $(21.44)^{* * *}$ & 1.971 & $(21.43) * * *$ & 1.999 & $(22.27)^{* * *}$ & 1.986 & $(21.95)^{* * *}$ \\
\hline$\Sigma \mathrm{IND}, \Sigma \mathrm{YR}$ & \multicolumn{2}{|c|}{ Included } & \multicolumn{2}{|c|}{ Included } & \multicolumn{2}{|c|}{ Included } & \multicolumn{2}{|c|}{ Included } \\
\hline Pseudo R2 & \multicolumn{2}{|c|}{0.082} & \multicolumn{2}{|c|}{0.082} & \multicolumn{2}{|c|}{0.084} & \multicolumn{2}{|c|}{0.083} \\
\hline Likelihood Ratio & \multicolumn{2}{|c|}{$266.91 * * *$} & \multicolumn{2}{|c|}{$266.24^{* * *}$} & \multicolumn{2}{|c|}{$272.67^{* * *}$} & \multicolumn{2}{|c|}{$271.21^{* * * *}$} \\
\hline Sample Size & \multicolumn{2}{|c|}{2335} & \multicolumn{2}{|c|}{2335} & \multicolumn{2}{|c|}{2335} & \multicolumn{2}{|c|}{2335} \\
\hline
\end{tabular}

This table presents the results of testing the effects of family firm and chaebol status on CSR activities. We performed a logit analysis using KEJI-listed companies as the dependent dummy variable. See Section 2 for variable definitions. ${ }^{* * *}$, ${ }^{* *}$, and ${ }^{*}$ represent significance at the $1 \%, 5 \%$, and $10 \%$ levels, respectively.

As can be seen in Columns (3) and (4) of Table 6, FAM1 $\times$ CHA and FAM2 $\times$ CHA, which denote cases where the family firms were classified as chaebols, had coefficient values of -0.515 and -0.477 , respectively, which were significantly negative values at the $5 \%$ level. These results indicate that although family firms tend to manage with a longterm perspective, when they are considered to be chaebols, their controlling shareholders have the tendency to pursue private profits given the firm's monopolistic status, thereby reducing CSR-related expenses. The results of the additional analysis using the CSR dummy variable support the robustness of the main analysis.

\subsubsection{Additional Analysis 2: CSR Scores}

As previously mentioned, the KEJI Index consists of six categories: soundness (25 points), fairness (20 points), social service activities (15 points), customer protection (15 points), environmental protection (10 points), and employee satisfaction (15 points). Table 7 shows the influence of family firm status on CSR activities for each specific category. Columns (2) and (3) indicate that family firms actively invest in observing fairness in corporate activities and volunteering activities when there are family members as controlling shareholders who participate in management. Fairness includes fair trade and corporate transparency, and social service activities include employment equality and expansion, contributions to public welfare, and financial contributions to the state.

Table 8 shows the influence of the chaebol status of family firms on CSR activities for each specific category. Columns (1) and (2) indicate that when a firm is considered to be a family firm or a chaebol, it reduces investment in activities related to soundness and fairness. The soundness aspect includes the soundness of the corporate governance structure, investment expenditure, and capital financing. These results indicate that chaebols whose controlling shareholders may seek private interests given their monopolistic status are passive in restructuring their governance structures and demonstrate a lack of transparency regarding capital procurement and expenditures. 
Table 7. Additional analysis 2: CSR subcategory scores.

\begin{tabular}{|c|c|c|c|c|c|c|c|c|c|c|c|c|}
\hline \multirow{2}{*}{ Variables } & \multicolumn{2}{|c|}{ (1) $Y=$ CSR1 } & \multicolumn{2}{|c|}{ (2) $Y=C S R 2$} & \multicolumn{2}{|c|}{ (3) $Y=C S R 3$} & \multicolumn{2}{|c|}{ (4) $Y=$ CSR4 } & \multicolumn{2}{|c|}{ (5) $Y=$ CSR5 } & \multicolumn{2}{|c|}{ (6) $Y=$ CSR6 } \\
\hline & Coef. & $t$-Value & Coef. & $t$-Value & Coef. & $t$-Value & Coef. & $t$-Value & Coef. & $t$-Value & Coef. & $t$-Value \\
\hline Intercept & 11.581 & $(10.69)^{* * *}$ & 21.010 & $(22.17)^{* * *}$ & 1.309 & $(1.25)$ & 10.757 & $(21.78) * * *$ & 0.785 & $(1.82) *$ & 10.404 & $(13.77)^{* * *}$ \\
\hline FAM1 & 0.105 & (1.05) & 0.243 & $(2.78)^{* * *}$ & 0.203 & $(2.11)^{* *}$ & -0.080 & $(-1.75) *$ & -0.009 & $(-0.24)$ & 0.081 & (1.17) \\
\hline $\mathrm{CHA}$ & 0.446 & $(3.39)^{* * *}$ & -1.148 & $(-9.97) * * *$ & 0.377 & $(2.97)^{* * *}$ & -0.107 & $(-1.79)^{*}$ & 0.178 & $(3.41)^{* * *}$ & -0.065 & $(-0.72)$ \\
\hline SIZE & 0.197 & $(4.83)^{* * *}$ & -0.173 & $(-4.85)^{* * *}$ & 0.155 & $(3.93)^{* * *}$ & -0.029 & $(-1.56)$ & 0.149 & $(9.18)^{* * *}$ & -0.034 & $(-1.23)$ \\
\hline LEV & -0.190 & $(-4.86)^{* * *}$ & 0.013 & $(0.4)$ & -0.035 & $(-0.94)$ & -0.006 & $(-0.35)$ & 0.022 & (1.46) & -0.054 & $(-1.99) * *$ \\
\hline MB & 0.095 & $(2.36)^{* *}$ & 0.021 & $(0.62)$ & 0.225 & $(5.77)^{* * *}$ & -0.061 & $(-3.35)^{* * *}$ & -0.002 & $(-0.15)$ & 0.013 & $(0.49)$ \\
\hline $\mathrm{ROE}$ & 0.135 & $(0.7)$ & -0.240 & $(-1.43)$ & 0.164 & $(0.89)$ & 0.022 & $(0.25)$ & 0.093 & $(1.21)$ & 0.236 & $(1.76) *$ \\
\hline LAR & -3.856 & $(-14.35)^{* * *}$ & -0.261 & $(-1.11)$ & -0.208 & $(-0.81)$ & 0.014 & $(0.11)$ & -0.163 & $(-1.53)$ & -0.250 & $(-1.34)$ \\
\hline FOR & 2.451 & $(6.73)^{* * *}$ & 0.145 & $(0.46)$ & 0.204 & $(0.58)$ & -0.145 & $(-0.88)$ & 0.578 & $(3.99)^{* * *}$ & -0.346 & $(-1.37)$ \\
\hline$\Sigma \mathrm{IND}, \Sigma \mathrm{YR}$ & \multicolumn{2}{|c|}{ Included } & \multicolumn{2}{|c|}{ Included } & \multicolumn{2}{|c|}{ Included } & \multicolumn{2}{|c|}{ Included } & \multicolumn{2}{|c|}{ Included } & \multicolumn{2}{|c|}{ Included } \\
\hline Adjusted R2 & \multicolumn{2}{|c|}{0.4703} & \multicolumn{2}{|c|}{0.4058} & \multicolumn{2}{|c|}{0.1270} & \multicolumn{2}{|c|}{0.8886} & \multicolumn{2}{|c|}{0.9190} & \multicolumn{2}{|c|}{0.2177} \\
\hline F Statistics & \multicolumn{2}{|c|}{$42.43^{* * *}$} & \multicolumn{2}{|c|}{$32.87^{* * * *}$} & \multicolumn{2}{|c|}{$7.79 * * *$} & \multicolumn{2}{|c|}{$373.23^{* * *}$} & \multicolumn{2}{|c|}{$530.13^{* * *}$} & \multicolumn{2}{|c|}{$13.98^{* * *}$} \\
\hline Sample Size & \multicolumn{2}{|c|}{1121} & \multicolumn{2}{|c|}{1121} & \multicolumn{2}{|c|}{1121} & \multicolumn{2}{|c|}{1121} & \multicolumn{2}{|c|}{1121} & \multicolumn{2}{|c|}{1121} \\
\hline
\end{tabular}

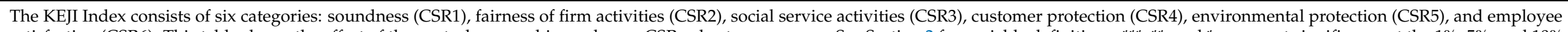

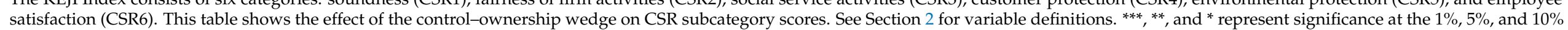
levels, respectively. 
Table 8. Additional analysis 2: CSR subcategory scores.

\begin{tabular}{|c|c|c|c|c|c|c|c|c|c|c|c|c|}
\hline \multirow{2}{*}{ Variables } & \multicolumn{2}{|c|}{ (1) $Y=$ CSR1 } & \multicolumn{2}{|c|}{ (2) $Y=\operatorname{CSR} 2$} & \multicolumn{2}{|c|}{ (3) $Y=$ CSR3 } & \multicolumn{2}{|c|}{ (4) $Y=C S R 4$} & \multicolumn{2}{|c|}{ (5) $Y=$ CSR5 } & \multicolumn{2}{|c|}{ (6) $Y=\operatorname{CSR} 6$} \\
\hline & Coef. & $t$-Value & Coef. & $t$-Value & Coef. & $t$-Value & Coef. & $t$-Value & Coef. & $t$-Value & Coef. & $t$-Value \\
\hline Intercept & 11.019 & $(10.23)^{* * *}$ & 20.603 & $(21.77)^{* * *}$ & 1.253 & $(1.19)$ & 10.705 & $(21.55)^{* * *}$ & 0.805 & $(1.86)^{*}$ & 10.261 & $(13.52)^{* * *}$ \\
\hline FAM1 & 0.434 & $(3.65)^{* * *}$ & 0.481 & $(4.6)^{* * *}$ & 0.236 & $(2.04)^{* *}$ & -0.049 & $(-0.90)$ & -0.021 & $(-0.45)$ & 0.165 & $(1.97) * *$ \\
\hline FAM $1 \times$ CHA & -1.013 & $(-4.98)^{* * *}$ & -0.733 & $(-4.1)^{* * *}$ & -0.100 & $(-0.51)$ & -0.093 & $(-1.00)$ & 0.036 & $(0.45)$ & -0.257 & $(-1.8)$ * \\
\hline $\mathrm{CHA}$ & 1.030 & $(5.88)^{* * *}$ & -0.725 & $(-4.71)^{* * *}$ & 0.435 & $(2.55) * *$ & -0.053 & $(-0.66)$ & 0.157 & $(2.23)^{* *}$ & 0.082 & $(0.67)$ \\
\hline SIZE & 0.207 & $(5.11)^{* * *}$ & -0.166 & $(-4.69)^{* * *}$ & 0.156 & $(3.95)^{* * *}$ & -0.028 & $(-1.52)$ & 0.149 & $(9.14)^{* * *}$ & -0.032 & $(-1.14)$ \\
\hline LEV & -0.208 & $(-5.35)^{* * * *}$ & 0.001 & $(0.03)$ & -0.037 & $(-0.98)$ & -0.007 & $(-0.44)$ & 0.023 & (1.49) & -0.058 & $(-2.14) * *$ \\
\hline MB & 0.089 & $(2.24)^{* *}$ & 0.017 & $(0.5)$ & 0.225 & $(5.75) * * *$ & -0.062 & $(-3.38)^{* * *}$ & -0.002 & $(-0.13)$ & 0.012 & $(0.43)$ \\
\hline $\mathrm{ROE}$ & 0.139 & $(0.73)$ & -0.237 & $(-1.42)$ & 0.164 & $(0.89)$ & 0.022 & $(0.25)$ & 0.092 & $(1.21)$ & 0.237 & $(1.77) *$ \\
\hline LAR & -3.738 & $(-14.01)^{* * *}$ & -0.175 & $(-0.75)$ & -0.196 & $(-0.76)$ & 0.024 & $(0.20)$ & -0.167 & $(-1.56)$ & -0.220 & $(-1.17)$ \\
\hline FOR & 2.460 & $(6.83)^{* * *}$ & 0.152 & $(0.48)$ & 0.205 & $(0.58)$ & -0.144 & $(-0.87)$ & 0.578 & $(3.98)^{* * *}$ & -0.344 & $(-1.36)$ \\
\hline$\Sigma$ IND, $\Sigma$ YR & \multicolumn{2}{|c|}{ Included } & \multicolumn{2}{|c|}{ Included } & \multicolumn{2}{|c|}{ Included } & \multicolumn{2}{|c|}{ Included } & \multicolumn{2}{|c|}{ Included } & \multicolumn{2}{|c|}{ Included } \\
\hline Adjusted R2 & \multicolumn{2}{|c|}{0.4815} & \multicolumn{2}{|c|}{0.4143} & \multicolumn{2}{|c|}{0.1265} & \multicolumn{2}{|c|}{0.8886} & \multicolumn{2}{|c|}{0.9189} & \multicolumn{2}{|c|}{0.2193} \\
\hline F Statistics & \multicolumn{2}{|c|}{$42.61^{* * *}$} & \multicolumn{2}{|c|}{$32.69^{* * *}$} & \multicolumn{2}{|c|}{$7.49^{* * *}$} & \multicolumn{2}{|c|}{$358.35^{* * *}$} & \multicolumn{2}{|c|}{$508.56^{* * *}$} & \multicolumn{2}{|c|}{$13.858^{* * *}$} \\
\hline Sample Size & \multicolumn{2}{|c|}{1121} & \multicolumn{2}{|c|}{1121} & \multicolumn{2}{|c|}{1121} & \multicolumn{2}{|c|}{1121} & \multicolumn{2}{|c|}{1121} & \multicolumn{2}{|c|}{1121} \\
\hline
\end{tabular}

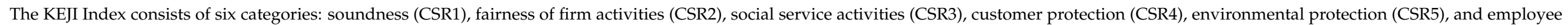

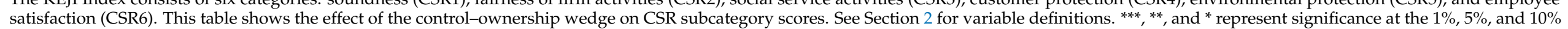
levels, respectively. 


\section{Conclusions}

This study analyzed Korean family firms to determine whether family firms were more active in carrying out CSR activities as compared to non-family firms. Family firms in Korea are either controlled by their founders and their families or are owned and managed by controlling shareholders and their families. Due to the nature of its corporate governance, a family firm experiences an alignment of interest between its shareholders and management and is managed with a long-term perspective based on a sense of ownership.

This study considered family firms as firms in which family members that were controlling shareholders participated in management, and the firms' CSR activity levels were identified using the annual KEJI Index published by the Institute of Economic Justice in Korea. The KEJI Index provides a list of 200 firms with superior CSR activities by year, as well as their scores.

The analysis showed that family firms had high KEJI Index scores, confirming that family firms were more active in CSR activities than non-family firms. Investments in CSR, by nature, are not directly related to performance, incur related costs, and occur over the long term. CSR activities have the advantage of enhancing a company's reputation and brand image, ultimately increasing corporate value. In the case of family companies, we predicted that there is an incentive to actively engage in CSR activities, as they make management decisions from a long-term perspective, and the results support Hypothesis 1.

On the other hand, some Korean family firms are characterized as chaebol groups. Korean chaebols are made up of several firms that operate in different markets, and they often have monopolistic positions in their markets. If the controlling shareholders use their monopolistic positions to pursue private profits, they tend to reduce CSR-related expenditures whose recovery is often uncertain [31]. The analysis indicated that if a family firm was considered a conglomerate (chaebol), it had a lower KEJI Index score. This result indicates that family firms considered to be chaebols enjoy monopolistic market positions with their affiliates and are more incentivized to redirect the resources utilized in CSR to other projects that are more aligned with their pursuit of private profits.

Additionally, this study utilized inclusion in the KEJI Index list (top 200 firms) as a dependent variable to conduct a logit analysis. The analysis revealed that family firms were more likely to be included in the top 200 firms if they performed CSR activities. On the other hand, family firms considered as chaebols were not included in the KEJI Index list. The results of the additional analysis are in line with those of the main analysis.

The results of this study indicate that CSR activity levels differ between firms according to family firm status. These findings of our study contribute to existing studies on the influence of firm ownership and governance structure on CSR investments. At the same time, this study found that family firms, which manage firms with longer-term perspectives compared to non-family firms, are active in CSR-related activities that are not directly related to short-term performance, but ultimately contribute to firm value in the long term, and we aimed to provide implications for the benefits of family firms.

Unlike Western family companies, Korean chaebols operate under concepts, such as "the succession of management rights" in terms of corporate governance. The fact that management and ownership are dominated by the owner's family is considered to be the cause of the Korea Discount, and performance is also devalued. On the other hand, there is another point of view that focuses on the efficiency of the Korean family governance structure, particularly in times of economic crisis. Conflicting views suggest that it is worth conducting research on Korean companies [49-53].

This study analyzed the level of CSR investment by chaebol companies, but it is limited in that it did not reflect the ownership-control gap in chaebol companies. East Asian companies are characterized by their stock ownership being concentrated with a small number individuals and by the controlling shareholders exerting enormous control over the company as a whole [54-56]. In particular, in countries where the level of protection for minority shareholders is insufficient, such as Korea, the controlling shareholder exerts stronger control over the entire company than the direct ownership through a pyramidal 
governance structure and mutual cross-ownership of stocks [57-59]. As a future research direction, it is necessary to analyze how CSR investment varies depending on the level of difference between ownership and control of chaebol family companies.

Author Contributions: Conceptualization, H.R.; methodology, S.-J.C.; formal analysis, H.R. and S.J.C.; writing-original draft, H.R. and S.-J.C.; writing—review and editing, H.R. and S.-J.C.; funding acquisition, H.R. All authors have read and agreed to the published version of the manuscript.

Funding: This work was supported by the Ministry of Education of the Republic of Korea and the National Research Foundation of Korea (NRF-2020S1A5A8041170).

Institutional Review Board Statement: Not applicable.

Informed Consent Statement: Not applicable.

Data Availability Statement: Not applicable.

Conflicts of Interest: The authors declare no conflict of interest.

\section{References}

1. Frooman, J. Socially irresponsible and illegal behavior and shareholder wealth. Bus. Soc. 1997, 36, 221-249. [CrossRef]

2. McWilliams, A.; Siegel, D. Corporate social responsibility and financial performance: Correlation or misspecification? Strateg. Manag. J. 2000, 21, 603-609. [CrossRef]

3. Hopkins, M. Corporate Social Responsibility: An Issue Paper; International Labour Office Working Paper No. 27; International Labour Organization (ILO)_Policy Integration Department: Geneva, Switzerland, 2014. [CrossRef]

4. Brown, T.J.; Dacin, P.A. The company and the product: Corporate associations and consumer product responses. J. Mark. 1997, 61, 68-84. [CrossRef]

5. Sen, S.; Bhattacharya, C.B. Does doing good always lead to doing better? Consumer reactions to corporate social responsibility. J. Mark. Res. 2001, 38, 225-243. [CrossRef]

6. Luo, S.; Bhattacharya, C.B. Corporate social responsibility, customer satisfaction and Market Value. J. Mark. 2006, 70, 1-18. [CrossRef]

7. Mackey, A.; Mackey, T.B.; Barney, J.B. Corporate social responsibility and firm performance: Investor preferences and corporate strategies. Acad. Manag. Rev. 2007, 32, 817-835. [CrossRef]

8. Freedman, M. The Social Responsibility of Business Is to Increase Its Profits. The New York Times 1970. Available online: https: / / www.nytimes.com/1970/09/13/archives/a-friedman-doctrine-the-social-responsibility-of-business-is-to.html (accessed on 10 January 2021).

9. Heal, G. Corporate social responsibility: An economic and financial framework. Geneva Pap. Risk Insur. Issues Pract. 2005, 30, 387-409. [CrossRef]

10. Freeman, R.E. Strategic Management: A Stakeholder Approach; Pitman Publishing: Boston, MA, USA, 1984.

11. Shleifer, A.; Vishny, R.W. Large shareholders and corporate control. J. Polit. Econ. 1986, 94, 461-488. [CrossRef]

12. Anderson, R.C.; Reeb, D.M. Founding family ownership and firm performance: Evidence from the S\&P 500. J. Finance 2003, 58, 1301-1328. [CrossRef]

13. Anderson, R.C.; Reeb, D.M. Founding-family ownership, corporate diversification, and firm leverage. J. Law. Econ. 2003, 46, 653-684. [CrossRef]

14. Ali, A.; Chen, T.Y.; Radhakrishnan, S. Corporate disclosures by family firms. J. Account. Econ. 2007, 44, 238-286. [CrossRef]

15. Kim, S.; Chae, S.J.; Lee, H.Y. The effects of corporate governance and ownership structure over conservatism of accounting information: Focusing on family-firm. Korean Manag. Rev. 2010, 39, 797-833. (In Korean)

16. Demsetz, H.; Lehn, K. The structure of corporate ownership: Causes and consequences. J. Polit. Econ. 1985, 93, 1155-1177. [CrossRef]

17. Jensen, M.C.; Meckling, W.H. Theory of the Firm: Managerial Behavior, Agency Costs and Ownership Structure. J. Financ. Econ. 1976, 3, 305-360. [CrossRef]

18. Gilson, R.J.; Gordon, J.N. Controlling controlling shareholders. Univ. Penn. Law Rev. 2003, 152, 785-843. [CrossRef]

19. Anderson, J.; Frankel, A. Voluntary social reporting: An ISO-beta portfolio analysis. Account. Rev. 1980, 15, 467-479.

20. Dhaliwal, D.; Li, O.; Tsang, H.; Yang, Y. Voluntary non-financial disclosure and the cost of equity capital: The initation of corporate social responsibility reporting. Account. Rev. 2011, 86, 59-100. [CrossRef]

21. Renneboog, L.; Ter Horst, J.; Zhang, C. Socially responsible investments: Institutional aspects, performance, and investor behavior. J. Bank Financ. 2008, 32, 1723-1742. [CrossRef]

22. Brammer, S.; Brooks, C.; Pavelin, S. Corporate social performance and stock returns: UK evidence from disaggregate measures. Financ. Manag. 2006, 35, 97-116. [CrossRef]

23. Pava, M.L.; Krausz, J. The association between corporate social responsibility and financial performance: The paradox of social cost. J. Bus. Ethics 1996, 15, 321-357. [CrossRef] 
24. Lev, B.; Petrovits, C.; Radhakrishnan, S. Is doing goof good for you? How corporate charitable contributions enhance revenue growth. Strateg. Manag. J. 2010, 31, 182-200. [CrossRef]

25. Cho, S.J.; Chung, C.Y.; Young, J. Study on the relationship between CSR and financial performance. Sustainability 2019, 11, 343. [CrossRef]

26. Carroll, A.B. Ethical challenges for business in the new millennium: Corporate social responsibility and models of management morality. Bus. Ethics Q. 2000, 10, 33-42. [CrossRef]

27. Lantos, G.P. The boundaries of strategic corporate social responsibility. J. Consum. Mark. 2001, 18, 595-632. [CrossRef]

28. Porter, M.E.; Kramer, M.R. Strategy \& society: The link between competitive advantage and corporate social responsibility. Harv. Bus. Rev. 2006, 84, 1-14.

29. McWilliams, A.; Siegel, D. Creating and capturing value: Strategic corporate social responsibility, resource-based theory, and sustainable competitive advantage. J. Manag. 2011, 37, 1480-1495. [CrossRef]

30. Oh, W.Y.; Chang, Y.K.; Martynov, A. The effect of ownership structure on corporate social responsibility: Empirical evidence from Korea. J. Bus. Ethics 2011, 104, 283-297. [CrossRef]

31. Ryu, D.W.; Ryu, D.K. How does industrial concentration affect firms? An empirical study of the relationships industrial Concentration, firm value, and debt ratio. Korean Manag. Rev. 2013, 42, 435-456. (In Korean)

32. Coffey, B.S.; Fryxell, G.E. Institutional ownership of stock and dimensions of corporate social performance: An empirical examination. J. Bus. Ethics 1991, 10, 437-444. [CrossRef]

33. Jensen, M. Agency costs of free cash flow, corporate finance and takeovers. Am. Econ. Rev. 1986, 76, 323-329.

34. Stulz, R. Managerial discretion and optimal financing policies. J. Financ. Econ. 1990, 26, 3-27. [CrossRef]

35. Faccio, M.; Lang, L.; Young, L. Dividends and expropriation. Am. Econ. Rev. 2001, 91, 54-78. [CrossRef]

36. Handler, W.C. Methodological issues and consideration in studying family businesses. Fam. Bus. Rev. 1989, 2, 257-276. [CrossRef]

37. Westhead, P.; Cowling, M. Family firm research: The need for a methodological rethink. Entrep. Theory Pr. 1998, 23, 31-56. [CrossRef]

38. La Porta, R.; Lopez-de-Silanes, F.; Shleifer, A. Corporate ownership around the world. J. Financ. 1999, 54, 471-517. [CrossRef]

39. Claessens, S.; Djankov, S.; Lang, L.H. The separation of ownership and control in East Asian corporations. J. Financ. Econ. 2000, 58, 81-112. [CrossRef]

40. Andres, C. Large shareholders and firm performance-An empirical examination of founding-family ownership. J. Corp. Financ. 2008, 14, 431-445. [CrossRef]

41. Yoo, C.; Pae, J. Corporate charitable contributions: Business award winners' giving behaviors. Bus. Ethics Euro. Rev. 2016, 25, 25-44. [CrossRef]

42. Kim, B.; Pae, J.; Yoo, C. Business Groups and Tunneling: Evidence from Corporate Charitable Contributions by Korean Companies. J. Bus. Ethics 2019, 154, 643-666. [CrossRef]

43. Amato, L.H.; Amato, C.H. The effects of firm size and industry on corporate giving. J. Bus. Ethics 2007, 3, 229-241. [CrossRef]

44. El Ghoul, S.; Guedhami, O.; Kwok, C.C.; Mishra, D.R. Does corporate social responsibility affect the cost of capital? J. Bank. Financ. 2011, 35, 2388-2406. [CrossRef]

45. Fombrun, C.J.; Shanley, M. What's in a name? Reputation building and corporate strategy. Acad. Manag. J. 1990, 33, $233-258$.

46. Brammer, S.; Millington, A. Corporate Reputation and Philanthropy: An Empirical Analysis. J. Bus. Ethics 2005, 61, 29-44. [CrossRef]

47. Choi, J.; Wang, H. The promise of a managerial values approach to corporate philanthropy. J. Bus. Ethics 2007, 75, 345-359. [CrossRef]

48. Campbell, D.; Slack, R. The strategic use of corporate philanthropy: Building societies and demutualization defences. Bus. Ethics Euro. Rev. 2007, 16, 326-343. [CrossRef]

49. Cheung, Y.L.; Tan, W.; Ahn, H.J.; Zhang, Z. Does corporate social responsibility matter in Asian emerging markets? J. Bus. Ethics 2010, 92, 401-413. [CrossRef]

50. Nam, Y.S.; Jun, H. The shaping of corporate social responsibility in Korea's economic development. Glob. J. Bus. Manag. Account. 2011, 1, 10-20.

51. Sharma, B. Contextualising CSR in Asia: Corporate Social Responsibility in Asian Economies; Lien Centre for Social Innovation: Singapore, 2013.

52. Cho, E.; Chun, S.; Choi, D. International diversification, corporate social responsibility, and corporate governance: Evidence from Korea. J. Appl. Bus. Res. JABR 2015, 31, 743-764. [CrossRef]

53. Singh, P.J.; Sethuraman, K.; Lam, J.Y. Impact of corporate social responsibility dimensions on firm value: Some evidence from Hong Kong and China. Sustainability 2017, 9, 1532. [CrossRef]

54. Barnea, A.; Rubin, A. Corporate social responsibility as a conflict between shareholders. J. Bus. Ethics 2010, 97, 71-86. [CrossRef]

55. Dam, L.; Scholtens, B. Does ownership type matter for corporate social responsibility? Corp. Gov. 2012, 20, 233-252. [CrossRef]

56. Brickley, J.A.; Lease, R.C.; Smith, C.W. Ownership structure and voting on antitakeover amendments. J. Financ. Econ. 1988, 20, 267-291. [CrossRef]

57. Chang, S.J. Ownership structure, expropriation, and performance of group-affiliated companies in Korea. Acad. Manag. J. 2003, $46,238-253$. 
58. Surroca, J.; Tribó, J.A. Managerial entrenchment and corporate social performance. J. Bus. Financ. Account. 2008, 35, 748-789. [CrossRef]

59. Kim, W.S.; Park, K.; Lee, S.H. Corporate social responsibility, ownership structure, and firm value: Evidence from Korea. Sustainability 2018, 10, 2497. [CrossRef] 